\title{
The Drivers of Intellectual Sustainability in a Regional Agriculture, Cattle and Forest Farmstead
}

\begin{abstract}
:
Intellectual capital drivers emerge in the national and regional economies as a key source of integrated sustainability. The company under analysis is the largest Portuguese agriculture, cattle and forest farmstead, covering several marshlands. Located in the region of Lisbon and Tagus valley, the diversity of their activities (forest exploration; hunting; agriculture; wines and olive oil production; and tourism) requires an integrated research towards the identification and disclosure of drivers that best contribute for company reputation. Through a descriptive and exploratory case study approach, the intellectual capital drivers were mapped and structured. Thus, a set of sustainability drivers were identified, all of them aggregated in five categories (Certification; Brands and Trademarks; Awards; Alliances and Networks; and Biodiversity Reputation). Whilst a regional source of economic development, evidence also provides new insights towards the design of an intellectual sustainability scoreboard applicable to similar organizations worldwide.
\end{abstract}

Keywords: Intellectual capital, agriculture, intellectual sustainability drivers, intellectual property, regional development

\section{Introduction}

Information, as a new insight in the connection process within individuals and organizations, has launched the requisite of new rules (Shapiro and Varian, 1999) in the integrated management of networks. This assumption has been gradually conducting into a semantic dispersion around the concept of information and knowledge, driving multiple and profuse researches in this scientific domain. Innovation, as a structural driver for society's development, aligned with the contribution of information and communication technologies has become a critical source of strategic value and financial positioning. Quality oriented to sustainable productivity, and aligned with social and environmental responsibilities, have emerged as an important booster of competitiveness.

Within the semantic boundaries of intellectual capital, several other concepts have come out and developed. From an integrated framework, Knowledge, knowledge management, intellectual capital (Edvinsson and Malone, 1997; Saint-Onge and Armstrong, 2004), intangible assets (Sveiby, 1997; Lev, 2001; Lopes, 2010) or even digital capital (Tapscott et al., 2000) are concepts that accurately drive individuals and organizations into value creation and innovation. Organizations have intensified their activities of innovation in order to increase the value derived from products and processes. This innovation process, embodied in routines and merged from individuals and organizations actions, reflects the knowledge dynamic transformation conceptualized by Nonaka and Takeuchi (1995) and systematically adjusted by the academic and scientific communities in their subsequent researches. 
Broadly, the upsets around the concepts of time and space have been the cause of deep changes in organizations, based on the adoption of initiatives that seek for the identification of the true value drivers and thereby to find the source of sustainable competitive advantage. Thus, the paradigm of networks management is based on information sharing processes, and on knowledge capture, transformation and dissemination. The agility and feasibility of those processes contribute to the building process of an individual and collective organizational memory which conducts its sustainability performance.

From a financial and accounting perspective, the research about intangibles is based on their identification, their measurement and dissemination processes. Concerning organization's intellectual capital resources measurement, several approaches have also been followed: measurements based on cost, based on market prices or based on discounted future returns (income). Relating its dissemination, those resources have been capitalized and included in the organizations' balance sheets (in the cases supported by international accounting standard 38) or reported through complementary statements (intellectual capital reports, programs, scoreboards, ratios, qualitative approaches). Those measurement and disclosure approaches (Sonnier et al., 2008; Singh and Kansal, 2011; Branswijck and Everaert, 2012) tend to complement the traditional financial statements (balance sheet, profit and loss account, cash flows statements), providing a more comprehensive and integrated view of the factors that potentially create economic returns.

\section{Aims and objectives}

Based on a descriptive and exploratory approach, this paper aims to identify and characterize the drivers of intellectual capital in a Portuguese agriculture, cattle and forest farmstead. Due to its diversity of activities, value come from resources not measured, not included in the financial statements but disclosed to stakeholders through a non structured framework. Aligned with intellectual capital and contingency theories, and through a descriptive and interpretative methodology, we seek for the identification of sustainability drivers, most of them recognized by management but not linked as sources of strategic value.

\section{Intellectual capital: a retrospective approach}

Several and profuse developments have occurred around the concept of intellectual capital and, consequently, around the search and development of models and frameworks that can contribute for its measurement and disclosure. Traditionally spread into three vectors - human capital, structural capital and customer capital -, intellectual capital provides a dynamic view of value creation in 
organizations (Roos et al., 1997; Saint-Onge and Armstrong, 2004). Measure, manage and disclose these intangible resources (Lev, 2001; Lopes, 2010) are the new insights of the research in this scientific field. Broadly, those approaches focus on the search for appropriate correlations between intellectual capital and financial performance of the companies, as historically made, for tangible assets indeed.

As evidenced in practice, intellectual capital assumes a dynamic nature once knowledge is continuously converted into value (Nonaka and Takeuchi, 1995). Human capital can be generically defined as the capabilities (experience, skills, creativity, and general knowledge), collectively or individually owned, in order to meet the needs and expectations of stakeholders. Those capabilities reside in individuals, organizational routines and procedures and its protection is guaranteed by the agreements established between them and their employers. In many cases, some intellectual assets are internally developed and legally protected (intellectual property) by the companies through the national and international legal institutions (v.g. patents registered in European Patent Office, in the United Stated Patent and Trademark Office, among others).

Structural capital emerges as the infrastructure that organizations develop to convert those capabilities through a direct (information systems, software, work procedures, marketing plans and organizational knowledge) and indirect mechanisms. These mechanisms reside in tangible assets ( $v . g$. buildings, equipments, etc.) and in intangible resources as strategic and restructuring plans, relationships with suppliers and customers, alliances and networks, certifications, among others (Lopes, 2010). This structural component translates the facilitating context for the creation and consequent effect of knowledge leverage. It is intangible capital, in most cases more important and accurate than its physical dimension. If we include organizational culture, business history and intrinsic part of their management, human capital can also be understood as the source of knowledge that becomes the object that drives the company into its vision, mission, values and goals. In this transactional process, innovation developed by human capital is the key element that converts those capabilities and skills in integrated networks, in external organizational capabilities, in brands and trademarks, in processes and in other intangible and sustainability resources.

The third component (relational capital) evidences the relationships and networks within the company value system. It really covers the full range of networks with suppliers, distributors, business facilitators, and innovation contributors as universities and other scientific institutions. It also includes the mechanisms related to brands reputation and other external recognition procedures (v.g. awards and certifications). In essence, it translates the origin of the operational cash flows, assuming it an important source of sustainability and economic value creation (Lopes, 2012). 
From a pure accounting and financial point of view, intangibles includes patents, copyrights, brand names, customer lists, import quotas, computer software, marketing rights, specialized know-how, trade names, and other specific rights that typically can be conveyed by an owner without necessarily also transferring related physical assets (IASC, 2000). Thus, intangibles are, in essence, resources that have no physical substance but are identifiable, controlled by an entity with an expected future economic benefits. Broadly, those assets are measured at cost (purchase cost, including taxes and import duties, less any trade discount and rebates, plus any directly attributable expenditure incurred in their preparation for effective operation or costs incurred in the development phase) or subsequently measured at fair value if this value is determined on a reliable basis. In many cases, intangibles cannot be recognized by accounting rules, once they cannot comply with the accounting norms (v.g. internally generated software, brands and trademarks). However, companies should report their intangibles in separate classes as: 1. Brand names; 2. Licenses and franchises; 3. Mastheads and publishing lists; 4. Computer software; 5. Copyrights, patents and other industrial rights, service and operating right; 6. Recipes, formulae, models, designs and prototypes; and 7. Intangibles under development) as a complement of the information quality and comprehensiveness (Epstein and Mirza, 2005).

Intellectual property, as a particular dimension of intellectual capital, refers to know-how, patents, copyrights, registered designs and trademarks, trade secrets, and brands (Chang et al., 2005). Brands are names or symbols such as logos, trademarks or specific design whose main function is to distinguish goods or services of an organization of those who are detained and marketed by competitors. It is a sign identified by that the market identifies the products or services of a company, distinguishing them from those of other undertakings. If the registered (legal protection), the holder shall hold an exclusive that gives him the right to prevent third parties from using, without his consent. In companies, despite their measurement and inclusion in financial reports, brands and other related resources are drivers of value and therefore important repositories of potential financial returns. As mentioned by Smith (1997:88), "one of the most obvious economic effects of a trademark is that it allows the owner to establish a price for a product or service that are higher than those charged for similar goods or services".

Seethamraju (2003) seeks to highlight the importance of brands in the measurement of an organization or in the identification and measurement of specific drivers of intellectual capital in a specific organization. Thus, companies must improve their financial reports providing disclosures about the effects of their brands (Salinas and Amber, 2009) in the financial statements. Those brands and trademarks also appear associated with the value creation and important synergistic effects, namely a positive correlation with market valuation. Usually, it is expected a positive correlation 
between the voluntary information disclosure about the acquisition of trademarks and the value of a buyer's market.

Strategic alliances (technology or commercially based) can also be important sources of positive returns, although the reactions by investors depend on several factors including the size of the organizations involved and the areas covered by such alliances (Das et al., 1998; Elmuti et al., 2005). The potential to realize synergies through the sharing of common operations such as $R \& D$, production, distribution or sales has been recognized as a source of value where the leverage effects are more reliable. Uncertainty among investors increases where alliances are announced at a marketing level, contrary to what happens when they deal with technological features. The reason for this could be related to different levels of intangibility. The argument for such evidence is that technological alliances are more attractive to investors as source of future returns. Once the technology-based alliances (sometimes based on technologies embodied in patents) within SME are seen as the way to enter into new markets or as the process to expand existing ones. In large companies, technological alliances and networks are incorporated as the way to share value for both sides.

Koza and Lewin (2000) have identified, from an exploitation and use perspective, three types of strategic alliances: learning alliances, business partnerships and hybrid alliances. While learning alliances aim to reduce information asymmetries between involved parties and seek for the common creation of new knowledge, business partnerships are based on the existing capabilities and immediate results. Hybrid strategies look for opportunities towards the capture of value through existing assets and capabilities and through learning activities. To create new value is a fundamental characteristic in this type of strategy. Thus, their differences can then be summarized into five distinct perspectives: loyalty, control, absorbency, time horizon and success criteria.

Measuring intellectual capital can emerge as the most important challenge in the recent social sciences research, particularly in the field of accounting and corporate finance. Value creation and sustainability indicators analysis require new approaches, once empirical evidence has demonstrated that, increasingly, the value has its origin in the most invisible side of organizations. This evidence consolidates the importance attributed to intangibles and intellectual capital while drivers of value. Measurement and disclosure alternatives, based on new conceptualizations, still complain new evidence to gauge their reliability and feasibility. It is really unquestionable that the models historically used (based on tangible assets and in less complex environments) do not respond to the contemporaneous requirements of resources measuring and performance monitoring. Companies should increase the voluntary information disclosure to a wide range of stakeholders, increasingly informed and requiring for new insights. 


\section{The sustainability perspectives}

The usefulness of information for decision-making is now one of the critical issues in the designing process, towards the information dissemination to the companies' stakeholders. The dynamic transformation occurred in businesses and, consequently, inside the companies, requires more and better information to be disclosed in a timely way which should meet the expectations of its users. However, many are the features that determine the type, timing and intensity in which this information is disclosed.

There are several theories that have explained the multiple strengths and detractors that influence information disclosure: contingency theory (Reid and Smith, 2000), institutional theory (DiMaggio and Powell, 1991; Chapman et al., 2009) and legitimacy theory (Guthrie et al., 2004). However, other agents exist that determine the intensity and timeless of that dissemination. Companies' management avoids sometimes the voluntary disclosure of information, based on the unstructured information produced inside the organizations they manage. There is no linkage between value drivers and the income resulting from them. Any of those theories has its basis in a social contract between the company and its stakeholders, creating internal mechanisms to respond to changes that occur in the environment.

The contingency theory perspective assumes that general contingencies such as size of the organization, uncertainty and risk, technology and environmental pressures affect organizational development and operational processes. Thus, organizations can not develop a standardized structure to plan, organize and control their own activities and information disclosures. The institutional theory reflects the fact that organizations must constantly adapt to external expectations and changes, that is the pressures leading to the implementation of best practices in information dissemination. There is a trend to implement the same structures and practices over time in response to social demands which are dubbed in the literature as an institutional isomorphic (DiMaggio and Powell, 1991). In a traditional approach, organizations were more concerned with the standardization of routines and processes than with the adaptive capacity to changes in the environment. In the era of knowledge, such practices are no longer compatible with the informational requirements either with generalized volatility that pervades the economic and social contexts

The third theory (legitimacy theory) is based on the assumption of a social contract between the reporting entity and the society in which it operates (Guthrie et al., 2004). The disclosure of information turns out to be a way to relieve social pressure and legitimize the activities that the organization develops. It is an approach in which the connection between the entity and dichotomous social agents consolidate both the object as the substance of the transactions. The dialectic legitimized 
reinforces the emerging dimensions of social and environmental responsibility that increasingly are being integrated into systems management control. In a value added perspective, we understand those two dimensions as the consolidation of permissive and sustainable development. This approach clearly fits in companies publicly owned.

The topic of the information management usefulness is actually a quite diffuse scope. Based on multiple boosters: type of information user, informational needs, pressures emerging from capital markets, changes in the environment in which organizations develop their activities and, when appropriate, the requirements of regulators who can translate the most diverse political orientations. Thus, we cannot, in a bidirectional relationship, associate a single theory with entities and user's behavior (management and stakeholders). All those theories have specific determinants that incorporate individual and collective behaviors.

Intellectual capital and intangible sustainability has been usually translated and reported using multiple Key Performance Indicators (KPI) and through multiple types of scoreboards (Kaplan and Norton, 1996; Lopes, 2012). Although they are identifiable and controlled by the entity, its essence lies in the organization, in contributing to the creation of future benefits. Broadly, sustainability is strongly supported by important intangibles that are not capitalized in the financial statements nor reported to stakeholders. In this scope, intangibles and sustainability can be reported through six dimensions as stated in the figure below [adapted from Lopes (2012)].

\section{Figure 1: The sustainability dimensions}

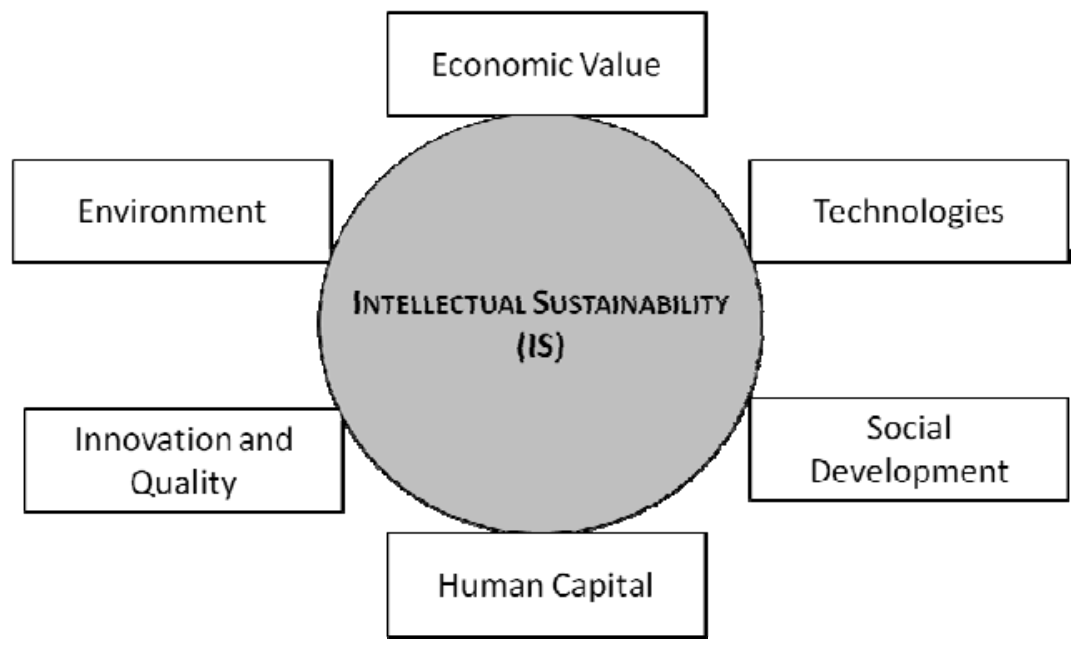

This framework reflects a strategic holistic model that allows individuals, groups and organizations to understand, through an integrated view, the Sustainability Performance Indicators $\left(\mathrm{SPI}_{\mathrm{n}}\right)$, most of 
them based on intangible resources. It enables organizations to align strategies, to identify their goals and to evaluate on an ongoing basis, its performance in each of those six dimensions.

\section{Methodology}

Several methods exist in order to identify the intellectual capital drivers disclosed by companies. Some of them are based on causal maps and cause-effect linkages (Montemari and Nielson, 2013), others use the content analysis of management reports as the best method to categorize those drivers (Abhayawansa, 2011). In this research, content analysis was the main method used to identify the potential value drivers that are not recognized in the financial statements or disclosed through integrated and structured complimentary reports. Through a descriptive and exploratory case study approach (Sekaran and Bougie, 2013), and based on the literature review, we seek for the identification of intangibles that can positively contribute for the company strategic and financial positioning. This interpretative approach provides deep and rich understandings of the social nature of practices, and attempts to locate these practices in the organizational specific context (Ryan et al., 2002). This holistic orientation aims to identify the core intangibles of the company and disseminate them through standardized reports and using multiple platforms as electronic networks. Using a normative reasoning, it is also intended to indicate to management, in the forthcoming research steps, what should be done in practice. Observation will complement and consolidate all the issues that emerge in this exploratory phase.

The company under analysis [Companhias das Lezírias (CL)] is the largest Portuguese agriculture, cattle and forest farmstead, covering several marshlands. Situated in the region of Lisbon and Tagus valley, this company is an important source of regional and national development in the agriculture sector. After the pastures and the fodder production area, rice is the predominant crop, covering an area of 1,100 hectares, followed by 140 hectares of corn. It was nationalized in 1975 and later, in 1989, it became a public limited company wholly owned by public funds. Since 1997, the company has consolidated its situation over time in both technological and financial terms, based on a sustained development philosophy.

CL sustainability and productivity is recognized as derived from the great set of natural assets it holds. At the threshold of Lisbon, with almost $200 \mathrm{~km}^{2}$ of land and occupying marshland and heath, is subject to strong management constraints due to its location in a protected area of the Natura 2000 network. The company operates some 7000 ha of agro forestry system, unique in the world, the cork oak forest with natural grass and improved pastures where the nearly four thousand head of cattle and 140 pets horses Lusitano. Company extracts an average of forty thousand kilos of cork by year. But 
beyond its economic value, the fitted also has a strong environmental value because it is a land use appropriate to the moorland, covering the major aquifer of the left side of the Tagus River, whose protection does not allow the intensification of production.

The company also produces many other goods and services. Strategically, and in the horizon term of a drastic decline in public support for farming activity in the context of Common Agricultural Policy, the market orientation in productions with particular conditions success is based on rice, wine and olive oil in the agricultural sector, and beef or organic in the livestock sector. On their own and integrated production, rice occupies about 220 ha of bogs, with a predominance of the variety Ariete Rice Carolino' s Wetland, first European geographical protection indication for this production. Strong investment in improving the structural conditions of culture was carried out in the last couple of years, which income rise finally normal. The same type of investment continues now in land rice that the company leases.

The identification of specific intangibles (certificates, brands, awards, networks, alliances, among others) was carried out through a content analysis process (v.g. management and sustainability reports and other documentation available through multiple platforms) and through direct observation. Through dynamic processes of mapping and subsequent categorization (Abhayawansa, 2011; Montemari and Nielsen, 2013) it was possible to identify a set of drivers, recognized by management as the main drivers of value creation. The measurement methods were pushed into the background by the management, mainly due to difficulties in finding reliable models to assess its fair value. Other intellectual capital drivers as satisfaction, databases, software, human capital, management systems, among others, were excluded from the current analysis. Our main focus was the intellectual property (Chang et al., 2005; Mukhtar, 2013) directly derived from agriculture, cattle and forest farmstead.

\section{Discussion and conclusion}

\subsection{Sustainability indicators}

As stated in figure 1, company sustainability is structured around six leading causal strengths: 1 . Economic value creation; 2. Environment; 3. Innovation and quality; 4. Information and communication; 5. Social development; and 6. Human resources (Lopes, 2012). Table 1 evidences a set of key performance indicators used by CL and usually disclosed to the stakeholders on a yearly basis. However, this information is disclosed through a non structured framework. 
Concerning the environmental perspective, it should be noted that much of the area is included in the CL Nature Reserve of Tagus estuary and Special Protection Area (KPI 9 ). Therefore, there is a constant concern in the alignment of their farming, forestry and livestock strategies with the conservation of the environment promotion of biodiversity and natural resources. Besides the fact that CL is a member of the Council for Sustainable Entrepreneurial Development, the main strategies can be described as follows: 1. the adoption of the method of integrated and organic production, in extensive; 2. Natural pastures; 3. Forest model with international certification of their management (cork oak); 4. Applied research projects in the area of the environment, in association with several universities; 5 . Respect for the birds, as evidenced by European projects as Birds Watching Project, carried out by $\mathrm{CL}$ as project promoter, in association with its partners such as associations of farmers, environmentalists, local government authorities, central government and companies.

Table 1: Sustainability performance indicators

\begin{tabular}{|c|c|c|c|}
\hline $\mathbf{S P I}_{\mathbf{n}}$ & Description & Unit & Value \\
\hline 1 & Gross revenues & '000€ & 7.286 \\
\hline 2 & $\begin{array}{l}\text { Earnings before interests, taxes, } \\
\text { depreciation and amortization }\end{array}$ & '000€ & 2.278 \\
\hline 3 & Net investments & '000€ & 674 \\
\hline 4 & Return on equity & $\%$ & 2,97 \\
\hline 5 & Permanent employees & \# & 98 \\
\hline 6 & Employees productivity & '000€ & 21,1 \\
\hline 7 & Water consumption & ' $000 \mathrm{~m}^{3}$ & 4.519 \\
\hline 8 & Energy consumption & TJ & 13,3 \\
\hline 9 & Natura area (protected area) & ha & 1.900 \\
\hline 10 & Forest area (model) & ha & 4.328 \\
\hline 11 & Biologic production area & ha & 8.670 \\
\hline 12 & Fossil dioxide carbon emissions & $\mathrm{Kg} / \mathrm{t} \mathrm{CO}_{2}$ & 85,7 \\
\hline 13 & Gas greenhouse emissions & $\mathrm{T} \mathrm{CO}_{2} \mathrm{eq}$ & $84.952,66$ \\
\hline 14 & Social intervention & $000 €$ & 240 \\
\hline
\end{tabular}

Source: Companhia das Lezírias (2012) annual reports

Although the company evidences a weak return on equity ( $\left.\mathrm{SPI}_{1}\right)$, CL has a positive operational return as evidenced by its EBITDA ( $\left.\mathrm{SPI}_{2}\right)$. These positive returns also derive from the company intellectual capital, not measured nor included in the financial statements (v.g. commercial brands and trademarks, awards, certificates, alliances, networks). Despite the accounting limitation in their recognition, $\mathrm{CL}$ tries to disclose them in its yearly reports, matching the information quality and comprehensiveness. 


\subsection{Intellectual sustainability strengths}

The activities of CL includes traditional agricultural products for sale, such as rice, olive oil and wine, forest products, and a set of extended services to the community in the fields of recreation, environmental education and support to scientific knowledge. In this research, and based on the requirements stated in International Accounting Standard 38 (IASC, 2000) scope, we tried to identify the intangible resources that are not included in the traditional financial statements but constitute important drivers for the company sustainability. These drivers are based on the operational activities and include external recognition with impact in the expected future benefits and returns.

The company is certified in most of its essential activities, namely in the forest management processes $\left(\mathrm{ISD}_{1}\right)$ and in some of its rice brands $\left(\mathrm{ISD}_{2}\right)$. In this particular case, it is produced through an integrated protection process, following a full process of combating crop pests and using methods that meet ecological requirements and toxicological restrictions (productions are made in respect to economic thresholds, with specific and biodegradable herbicides, but without insecticides). These conditions are the basis of the market recognition of their rice varieties and trademarks, such as Ariete; Albatroz; Carolino's Wetland; and Bom Sucesso (ISD 7 ).

CL has also an important range of grapes' varieties (23), allowing a range of products with various niche markets, including varietal, blended wines, sparkling wines, and spirits, which have earned good critical reception and placement in the national and international markets $\left(\mathrm{ISD}_{6}\right.$ and $\mathrm{ISD}_{11)}$. The main castes used in the wines production are: Castellan and Alicante Bouschet, for the production of red wines, Fernão Pires and Trincadeira das Pratas for white wines. Other red varieties are: Trincadeira, Aragonez, Touriga- Nacional, Cabernet Sauvignon, Syrah, Merlot, etc.. The white wines' varieties include: Arinto, Wardrobe, Talia, Verdelho and Vital.

The table 2 evidences the main intellectual sustainability drivers, identified in the company and disclosed, through a non structured framework, to the stakeholders as a whole. These drivers were grouped in five classes, according their substance and origin (1. certification; 2. brands and trademarks; 3. awards; 4. networks and alliances; and 5. ecological reputation). As already mentioned in the methodology, standard intangibles as software, management systems, customers lists, and patents, were excluded from this scope of analysis. 
Table 2: Intellectual sustainability drivers

\begin{tabular}{|c|c|c|}
\hline Dimension & ISD $_{\mathbf{n}}$ & Intellectual Sustainability Drivers \\
\hline \multirow[t]{2}{*}{ CERTIFiCATION } & 1 & $\begin{array}{l}\text { Forest management certification } \\
\text { Stewardship Council Standards) }\end{array}$ \\
\hline & 2 & Brands certification (ISO 9001:2008) \\
\hline \multirow{5}{*}{$\begin{array}{l}\text { BRANDS AND } \\
\text { TRADEMARKS }\end{array}$} & 3 & $\begin{array}{l}\text { Wines (v.g. Samora; Catapereiro; Azul Portugal; } \\
\text { Companhia das Lezírias; etc.) }\end{array}$ \\
\hline & 4 & Olive oil (v.g. Azeite Virgem Extra) \\
\hline & 5 & Horses (Lusitano) \\
\hline & 6 & $\begin{array}{l}\text { Grapes castes (v.g. Aragonez, Touriga- Nacional, } \\
\text { Cabernet Sauvignon, Syrah, Merlot, etc.) }\end{array}$ \\
\hline & 7 & $\begin{array}{l}\text { Rice varieties (v.g. Ariete; Albatroz; Carolino' s } \\
\text { Wetland; Bom Sucesso) }\end{array}$ \\
\hline \multirow{5}{*}{ AWARDS } & 8 & Lusitano horse lineage \\
\hline & 9 & Olive oil \\
\hline & 10 & Horses breeding \\
\hline & & Wines (v.g. Shanghai International Wine Challenge \\
\hline & 11 & $\begin{array}{l}\text { 2010; Viniales Internationales; International Wine } \\
\text { Challenge) }\end{array}$ \\
\hline \multirow{3}{*}{$\begin{array}{l}\text { NETWORKS } \\
\text { AND } \\
\text { ALLIANCES }\end{array}$} & 12 & Agreements with customers (v.g. SONAE; SAVEN) \\
\hline & 13 & Alliances (v.g. Ovivárzea) \\
\hline & 14 & $\begin{array}{l}\text { Research and development projects (with } \\
\text { universities and other scientific institutes) }\end{array}$ \\
\hline ECOLOGICAL & 15 & Natura 2000 protected area \\
\hline REPUTATION & 16 & Biodiversity protection recognition \\
\hline
\end{tabular}

The forestry assets of the company are also very valuable. The most important productions are cork and pine woods, beyond timber and firewood, resulting from annual activity planning and management ( $\mathrm{ISD}_{15}$ and $\left.\mathrm{ISD}_{16}\right)$ as cultural and health cuts. The certification of sustainable forest management (ISD 1 ) by the Forest Stewardship Council (FSC), in 2010, consolidates the cork production as one of the main sources of future returns achievements. The purpose of accreditation is, particularly, a credible demonstration of the product market recognition, by which a certificate is included for timber and cork.

The company integrates a wide range of networks and alliances. Products usually reach the markets through selected and specialized distributors and wholesalers (ISD ${ }_{12}$ and $\mathrm{ISD}_{13}$ ), which are the basis of 
the external recognition ( $\mathrm{ISD}_{9}$ and $\mathrm{ISD}_{11}$ ). The products quality is strongly based on the research projects developed through universities (Elmuti et al., 2005) and other scientific institutes (ISD ${ }_{14}$ ). Thus, if the active forestry and agro-forestry is so important, its sustainable development requires deeper knowledge of the state of natural stocks and dynamics of values conservation that are influenced by the decisions of resource management. These projects integrate the research and development activities that support the company innovation capacity. The market approach associated with the development of products and processes that protect the environment and ecologically healthier, also constitute one of the most valuable and recognized intangible assets.

In this phase of research, we have evidenced that the company voluntarily discloses information concerning the forest management and protection, and concerning the productive activities related to it. The external recognition of those activities (certification, awards, ecological reputation, brands and trademarks recognition) consolidates the operational sustainability of the company. As a public company, we consider that the information disclosure in CL fits to the legitimacy theory, as argued by Guthrie et al. (2004). In fact, in companies publicly owned, we have evidence of a social contract (social and environmental responsibilities) between companies and the society in which it operates. The disclosure of the activities that effectively were developed turns out to the way to relieve social pressure and legitimize these activities. This underlines the approach in which the connection between the company and social agents consolidate the object and the substance of the integrated operations.

The company has focused primarily on the disclosure (Sonnier et al., 2008; Singh and Kansal, 2011; Branswijck and Everaert, 2012) of their brands ( $\mathrm{ISD}_{3}$ to $\mathrm{ISD}_{7}$ ) and strategic alliances (ISD 12 to ISD 14 ), although none procedure has been implemented to measure, recognize those intangibles in the financial reports (Koza and Lewin, 2000; Seethamraju, 2003; Chang et al., 2005). It has followed a strategy based on the voluntary disclosure of information. It is assumed by management that dissemination level is more relevant, from a point of view of the information usefulness and comprehensiveness than its measurement and valuation. The lack of financial models and the difficulty in measuring intangible resources is seen as the major obstacle to their inclusion in the financial statements and the reports, corroborating the previous evidence already provided by Lopes (2010).

The focus on research ( $\left.\operatorname{ISD}_{14}\right)$ is considered by the administration another important source of business value. Therefore, it is also recognized by the administration that the company has a long tradition of pioneering and innovation in agro -forestry sector financing various research projects related to their areas of activity. Within the Business \& Biodiversity initiatives, the company has established a commitment with the Institute for Nature Conservation and Biodiversity towards the development of several lines of applied researches (CL, 2012). 


\section{Final remarks and forthcoming research}

The central objective of this paper was the identification of the main intellectual drivers, as sources of future economic benefits that contribute to the company sustainability. Based on the intellectual capital and sustainability theories, and through a descriptive and exploratory approach, we were intended to identify the most recognized intangibles, not included in the traditional financial statements but recognized by management as important drivers and voluntarily disclosed to company stakeholders. However, this is only the first step of a deep research in which the main objective is the consolidation of a sustainability scoreboard, to be implemented in the company in the forthcoming times.

In this research, it was possible to identify 16 intellectual sustainability drivers which derive in expected future returns. These resources are not measured or included in the traditional financial statements. They do not comply with some requirements for intangible assets recognition, namely the feasibility in their measurement and the full control by the entity, as required by the main accounting standards. However, these value enablers are the basis of expected returns which are intended to be measured and financially reported through an income or market based approaches (Lopes, 2011).

Companhia das Lezírias does not apply for any structured intellectual capital model, as evidenced in the existing literature in this scientific field (Edvinsson and Malone, 1997; Roos et al., 1997; SaintOnge and Armstrong, 2004). However, the information disclosed to stakeholders is extensive and rich in what may be considered the basis of its economic return. While the theoretical framework of intellectual capital can be internally perceived, it urges the implementation of structuring mechanisms towards an structured mapping and disclosure of the leading operational sustainability drivers. The use of causal maps evidenced by Montemari and Nielson (2013) can be a key insight and tool to be used in the forthcoming research steps.

\section{References}

Abhayawansa, S. (2011). "A methodology for investigating intellectual capital information in analyst reports”, Journal of Intellectual Capital, Vol.12, No. 3, pp. 146-176.

Branswijck, D. and Everaert, P. (2012). "Intellectual capital disclosure commitment: myth or reality?", Journal of Intellectual Capital, Vol.13, No. 1, pp. 39-56. 
Chapman, C; Cooper, D. and Miller, P. (2009). "Linking Accounting, Organizations, and Institutions, in Chapman, C. and Miller, P. (Eds.) Accounting Organizations and Institutions, Oxford: University Press.

CL - COMPANHIA DAS LEZÍRIAS (2012). Sustainability Reports, http://www.cl.pt/htmls/en/empresa relatorios.shtml, accessed on October 2013.

Das, S.; Sen, P. K. and Sengupta, S. (1998). "Impact of strategic alliances on firm valuation", Academy of Management Journal, vol. 41, No 1, pp. 27-41.

DiMaggio, P. and Powell, W. (1991). "The iron Cage Revisited: Institutional Isomorphism and Collective Rationality in organization fields, In: Powell, W. and DiMaggio, P. (Eds.) The New Institutionalism in Organizational Analysis, Chicago: The University of Chicago Press.

Edvinsson, L. and Malone, M. (1997). Intellectual Capital: the proven way to establish your company's real value by measuring its hidden brainpower, London: Judy Piatkus.

Elmuti, D.; Abebe, M. and Nicolosi, M. (2005). "An overview of strategic alliances between universities and corporations", Journal of Workplace Learning, Vol.17, No 1/2, pp. 115-129.

Epstein, B. J. and Mirza, A. A. (2005). Interpretation and Application of international Accounting and Financial Reporting Standards, New Jersey: John Wiley \& Sons.

Guthrie, J.; Petty, R.; Yongvanich, K. and Ricceri, F. (2004). "Using Content analysis as a Research Method to Inquire into Intellectual Capital Reporting”, Journal of Intellectual Capital, 5(2), pp.: 282293.

IASC - International Accounting Standards Committee (2000). IAS 38 Intangible Assets, Teddington: Accountancy Tuition Centre.

Kaplan, R. S. and Norton, D. P. (1996). The Balanced Scorecard: Translating Strategy into Action, Boston, MA: Harvard Business School Press.

Lev, B. (2001). Intangibles: management, Measurement, and Reporting, Washington: Brookings Institution Press. 
Lopes, I. T. (2010). “Towards a complementary intangibles reporting approach”. Measuring Business Excellence, Emerald Group Publishing, IFKAD 2010 Special Issue, Daniela Carlucci and Antonio Lerro (Eds.), Vol. 14, Issue 4, pp. 24-34.

Lopes, I. T. (2011). "The Boundaries of Intellectual property Valuation: Cost, Market, Income Based Approaches and Innovation Turnover”. Intellectual Economics, 1(9), pp. 99-116.

Lopes, I. T. (2012). "Seeking for a Sustainable Development Scoreboard: Beyond the Agency Theory”, Journal of Social Technologies, Vol. 2 (2), pp. 273-289.

Montemari, M. and Nielsen, C. (2013). "The role of causal maps in intellectual capital measurement and management”, Journal of Intellectual Capital, Vol.14, No. 4, pp. 522-546.

Mukhtar, N. (2013). "Nature and Scope of Intellectual property: An Appraisal of Concepts, issues and Propects for Developing Economies", Journal of Policies and Law, Vol. 6, No 2, pp. 202-215.

Nonaka, I. and Takeuchi, H. (1995). The Knowledge - Creating Company, New York: Oxford University Press.

Reid, G. and Smith, J. (2000). "The Impact of Contingencies on Management Accounting System Development", Management Accounting Research,8, pp.:147-164.

Ryan, B.; Scapens, R. W. and Theobald, M. (2002). Research method \& Methodology in Finance \& Accounting, $2^{\text {nd }}$ edition, London: Thomson.

Roos, J.; Roos, G.; Dragonetti, N. C. and Edvinsson, L. (1997). Intellectual Capital: navigating the new business landscape, London: Macmillan Press.

Saint-Onge, H. and Armstrong, C. (2004). The Conductive Organization. Building Beyond Sustainability, Oxford: Elsevier.

Sekaran, U. and Bougie, R. (2013). Research Methods for Business, Sixth Edition, West Sussex: John Wiley \& Sons.

Shapiro, C. and Varian, H. R. (1999). Information Rules: a Strategic Guide to the Network Economy, Boston: Harvard Business School Press. 
Singh, S. and Kansal, M. (2011). "Voluntary disclosures of intellectual capital: An empirical evidence", Journal of Intellectual Capital, Vol.12, No. 2, pp. 301-318.

Sonnier, B. M.; Carson, K. D. and Carson, P. F. (2008). "Intellectual capital disclosure by traditional US companies: a longitudinal assessment”, Journal of Accounting \& Organizational Change, Vol.4, No. 1, pp. 67-80.

Sveiby, K. E. (1997). The New Organizational Wealth: managing and measuring knowledge-based assets, San Francisco, CA: Berrett-Kowhler Publishers.

Tapscott, D.; Ticoll, D. and Lowy, T. (2000). Digital Capital - Harnessing the Power of Business Webs, Boston, MA: Harvard Business Scholl Press. 